\title{
Achkasova 5. USING THE DECISION-MAKING TECHNOLOGY IN ORGANIZATION OF COMPLIANCE IN THE SPHERE OF ACCUMULATED PENSION PROVISION
}

The paper examines the combination of Google Trends search engine tools and the Decision Making Helper decision support system, taking into account the possibility of solving scientific problems in the compliance organization. The object of research is the compliance organization in the field of funded pension provision. One of the most problematic areas is the lack of research to assess the level of interest of users of the search engine Google Trends in the topic of compliance and the degree of its spread. This hinders the practice of identifying trends and current trends in the development of modern scientific, social and professional thought in the organization of compliance. The research used the tools of the Google Trends search engine based on the frequency of requests for this definition in Ukrainian, Russian and English. According to the frequency of search queries of users, trend models for the considered concepts of «compliance» have been built, having a satisfactory (0.859 and 0.7507) value of the approximation reliability. These two trend models are recommended for predicting the level of user interest in the compliance topic. So, it is modeled the process of assessing the level of interest of users of the Google Trends search engine by the «compliance» concept. This provides the advantage of being able to predict the interest of Google Trends users on the topic. The positive effect of the conducted research is to identify trends and current trends in the development of modern scientific, social and professional thought on compliance.

Obtained, using the Decision Making Helper decision support system, an assessment of alternatives for the key components of the organization's compliance in the area of funded pension provision. This is due to the fact that the proposed approach to decision-making has a number of features, including organizational, methodological and process aspects. In particular, the priority of the organizational aspect is determined, it has the characteristics of the most positive decision. This provides benefits such as automating decisions and the ability to prioritize those decisions.

Keywords: search engine, search query, compliance, user interest, accumulative pension provision.

\section{Introduction}

Globalization processes in the world increase the importance of the issue of organizing activities aimed at compliance with the requirements of legislation and internal procedures, that is, compliance, in various areas. Violation of these requirements may lead to the application of measures of influence by the relevant state regulation and supervision body or the occurrence of legal liability.

Let's consider the requirements for a compliance organization using the example of Ukraine. Ukraine has developed drafts of the Law of Ukraine «On Compulsory Accumulative Pension Provision» [1] and «On Compulsory Accumulative Pension Provision» (prepared by the National Commission on Securities and Stock Market) [2]. The innovations of these draft laws have requirements for the organization of compliance that confirms the relevance of its organization.

Obtaining confirmation that the issue of compliance is of interest (public, scientific, practical, etc.) is relevant to the internationalization of the research process and the development of self-education on key issues of business development.
Internet resources are a reference tool, have become a medium for processing and storing scientific, business and other types of information. But the main features of the Internet are the dynamics of information, its constant updating and distribution [3].

The experience of the Google search engine is progressive and meets the task of analyzing the level of user interest [4].

Obtaining information about the prevalence or nonprevalence of the topic of compliance on the Internet will allow to substantiate trends in the development of scientific and public thought on the organization of compliance. However, as indicated above, this is an innovation for the sphere of funded pension provision, since at the level of draft laws the requirements for the organization of compliance are justified. That is why, for the subjects carrying out compulsory accumulative pension provision and non-state pension provision, this issue is relevant. Considering this, the search for mechanisms, tools, techniques that will provide an opportunity to automate the process of making the right and priority decisions during its organization is relevant. The use of the decision support 
system (hereinafter - DSS) Decision Making Helper will allow the processing of qualitative information (and compliance is based mainly on qualitative variables), to provide a correct interpretation of the results of this processing. The availability and usability of the DSS Decision Making Helper will have a positive impact on the compliance process. That is why the development of recommendations on the use of decision-making technology when organizing compliance in the field of funded pension provision is relevant.

\section{The object of research and its technological audit}

The object of research is the organization of compliance in the field of funded pension provision. The ability and effectiveness of the organization of compliance in the field of funded pension provision depends on information, methodological and other support, which will serve as the basis for its organization. In turn, the assessment of the level of interest of users of the search engine Google Trends in the subject of compliance and the degree of its spread will allow determining a comprehensive view and the possibility of developing new approaches to its organization. This will contribute to the development of the practice of identifying trends and current trends in the development of modern scientific, social and professional thought on the organization of compliance in the field of funded pension provision. Using DSS Decision Making Helper can provide an opportunity to: automate the decision making process; prioritize these decisions. The combination of the Google Trends search engine toolkit and the Decision Making Helper DSS for solving scientific problems in the organization of compliance will provide an integrated approach to its organization.

\section{The aim and objectives of research}

The aim of research is to develop recommendations on the use of decision-making technology when organizing compliance in the field of funded pension provision.

To achieve this aim, it is advisable to solve the following objectives:

1. Assess the level of interest of users of Internet resources with the «compliance» concept using the Google Trends search engine.

2. Use the Decision Making Helper to decide on the key components of a funded pension compliance organization.

\section{Research of existing solutions of the problem}

When analyzing modern scientific research aimed at developing scientific thought on compliance, it is determined that the focus of scientific research is mainly focused on the compliance description in a static form. This describes compliance by the relevant department and/or in terms of modeling the processes associated with compliance. This explains the fact that the subject of compliance is often used in conjunction with the search for information technology solutions for modeling processes in an organization in order to comply with requirements. In particular, the legal requirements that changes over time, and the requirements of the organization in order to control internal procedures and policies.
In work [5], it is noted that in compliance management, it is important to use a technological solution (Business Process Management Notation). This will allow the support of a wide range of matching patterns representing an abstract specification of monitoring requirements [5]. This will allow a quick understanding of the compliance process by various stakeholders. However, the question of automating the process of making correct and priority decisions during its organization remains a challenge, which is especially important in conditions of uncertainty.

The work [6] confirms the importance of building business processes. It is also noted that compliance management should become an integral part of the organization's business process management. The paper notes that no matter how perfect the methods of using software to implement compliance may be, this process can't be fully automated. After all, having decision-making methods, they can only facilitate and improve the quality of the work performed by the compliance department. In [7], the author notes that the promising areas of research in the context of this research are the Bayesian network toolkit and the standard for the web ontology language (OWL2.0). So, all this makes it possible to assert that the issues of using expert assessments in the process of integrating compliance into the management of the organization's business processes are insufficiently researched. And expert assessments are the basis for the development of decision support systems.

The authors in the source [8] consider monitoring of internal and inter-organizational business processes as the basis for the implementation of compliance, the requirements for which should be flexible, but limited. However, it should be noted that the issue of taking into account the specifics of the organization of compliance for organizations in the field of accumulative pension provision is not sufficiently covered.

In [9], a study is carried out on the requirements for the creation of a compliance department within the organizational structure and functions of an employee responsible for compliance. And in the source [10], compliance is considered taking into account the organizational aspect of preventing the risk of money laundering in banks Therefore, it is advisable to state that the organizational aspect of implementing the compliance policy will become promising, taking into account modern trends in the development of organizations. The results obtained in the above works are solid considering the organizational aspect of compliance, leaving without attention the possibility of automating the decision-making process. Also, the issue of process and information support, which are important to meet the needs of various stakeholders in the field of funded pension provision.

Compliance is an interdisciplinary area. In particular, in the field of financial monitoring in banks, it has acquired particular importance. The Basel Committee on Banking Supervision has developed a report entitled «Compliance and the compliance function in banks», which defines the principles of the institutional organization of compliance [11]. Therefore, it is advisable to state that compliance is considered as a direction of regulation and supervision, given the importance of its implementation, in particular in the context of increasing the social responsibility of business. This, in turn, indicates the need for research aimed at unifying the procedure for organizing compliance, in particular in the area of accumulative pension provision. 
The source [12] discusses the problems of growth in the scale and dynamics of flows in the modern information space. The strengthening of the role of satisfying user requests through the development of search engines is noted. The features of the search engine, which are used to carry out traditional monitoring of a given topic in the information space, are given. However, the issue of conducting research on the practical application of search engine tools for assessing the level of interest in the topic of compliance has not been sufficiently researched.

The Google Trends research toolkit is used in [4] to identify interest in innovation trends through user search queries in Ukraine using Google in different languages for the concepts of «innovation», «startup», «innovative entrepreneurship», «business incubator». This work also used decision-making software to simulate the components of influence on the development of startups in the region, it was built taking into account the high asymmetry of the development of startups in the regions of Ukraine. The use of the analysis of Internet resources to assess the level of prevalence of the use of concepts in the field of risk assessment of lending to financial institutions is done in [13]. This study is carried out to substantiate the importance of the components of the concept of «risk assessment of lending to financial institutions» using the Google Trends toolkit. The importance of this issue is also confirmed by the development of the informatization process in society. That is, the combination of the Google Trends search engine toolkit in research and the DSS Decision Making Helper is important, given the possibility of solving scientific problems, will contribute to ensuring the complexity in the compliance organization.

However, in the aforementioned sources, the issues of using the Google Trends search engine tools to assess interest and the extent of the compliance topic have not been investigated. In addition, the issues of using the DSS Decision Making Helper to assess alternatives to key components of a compliance organization are not presented in the field of scientific research. Therefore, it is proposed to apply this merger process in the work to ensure an integrated approach to its organization.

\section{Methods of research}

To model the process of assessing interest and the use of decision-making technology in the compliance organization, the following methods are used:

- method of analysis of Internet resources - when determining the total frequency of search queries of users of the Google Trends search engine according to the considered «compliance» concept in Ukrainian, Russian and English;

- graphical method - when visualizing the total frequency of search queries of users of the Google Trends search engine for the considered «compliance» concept in Ukrainian, Russian and English;

- forecasting method using trend lines - when building models for predicting the level of interest of users of the Google Trends search engine on the subject of compliance;

- method of expert ranking and DSS Decision Making Helper - when assessing alternatives to the key components of the organization, compliance in the sphere of funded pension provision.

\section{Research results}

6.1. Assessment of the level of interest of users of Internet resources by the "compliance» concept using the Google Trends search engine. The topic of compliance is used in various fields of activity, especially in the banking sector, therefore, assessing the degree of distribution, interest of users and their interest in this area may indicate the development and prospects of this area among scientists and practitioners.

The «compliance» concept comes from the English compliance and from the verb to comply and means compliance with certain rules, requirements or conditions. In the context of business, compliance means the legality of the actions of the company as a whole and of each of its employees, from top management to all branches and divisions. For counterparties, compliance is a check that confirms compliance with legal requirements, applicable rules, norms of certain standards and/or the terms of the contract [14].

Compliance is a system of internal relations aimed at ensuring compliance with the requirements of legislation and other documents securing obligations assumed in the framework of the main activity, as well as preventing their violation. Also, compliance is a function of internal control, along with risk management and internal audit [1].

To assess general trends and interest in the topic of compliance, assess the relevance of this area among users, given the prevalence and relevance, the tools of the Google Trends information search system were used.

The leader among search engines is Google. Its performance exceeds 40 billion requests per month. Google Trends refers to convenient for traditional monitoring along with Google Alerts, advanced Google search, etc. With its help, it is possible to track topics in which there is interest [12].

Research that is based on the query language [15] can be widely disseminated.

Defragmenting will allow to apply the method of analyzing Internet resources with greater accuracy and reliability [13].

Strengthening the role, importance and relevance of introducing a compliance organization for the development of the economies of individual financial services markets, etc. it is proposed to carry out through the assessment of interest based on the frequency of user requests in the world and in Ukraine. For this purpose, a statistical base of the frequency of search queries, the compliance concept in the Ukrainian, Russian and English languages was formed using the tools of the Google Trends search engine, which allows to analyze statistics on search queries, regions, periods.

In order to analyze the interest on the part of various stakeholders in the search for information on the «compliance» concepts in Ukrainian, Russian and English, the frequency of their search queries in the context of countries according to the data starting from 2004 was analyzed (Table 1). All operations to form a statistical base on the frequency of search queries were carried out as of May 23, 2020.

As it is possible to see from the Table 1, taking into account the language peculiarities of each of the countries of the world, the «комплаєнс» concept was $100 \%$ interested in users from Ukraine. At this stage, it is advisable to determine the distribution of the frequency of user search queries in Ukraine, which was carried out further in the study. 
Table 1

Frequency of user inquiries in the world in terms of "compliance» in Ukrainian, Bussian and English by country, \%

\begin{tabular}{|c|c|c|}
\hline «Комплаєнс» & «Комплаенс» & $\begin{array}{l}\text { «Compliance» are given for } \\
\text { the top ten most frequently } \\
\text { searched countries of the world }\end{array}$ \\
\hline \multirow{10}{*}{ Ukraine - 100} & Kazakhstan - 100 & Saint Helena island - 100 \\
\hline & Russia - 54 & Singapore - 75 \\
\hline & Кугgyzstan - 52 & Hong Kong -73 \\
\hline & Ukraine - 30 & Luxembourg -73 \\
\hline & Uzbekistan - 27 & Australia - 71 \\
\hline & Belarus - 26 & South Africa - 68 \\
\hline & \multirow{4}{*}{ Mongolia - 24} & New Zealand - 60 \\
\hline & & Kenya - 53 \\
\hline & & U5A - 53 \\
\hline & & Ireland -51 \\
\hline
\end{tabular}

Note: based on data from Google Trends by source [16]

The interest of users in information on the «комплаенс» concept in Russian is defined in the following countries (with frequency of use): Kazakhstan - $100 \%$, Russia - 54\%, Kyrgyzstan - $52 \%$, Ukraine - $30 \%$, Uzbekistan - $27 \%$, Belarus - $26 \%$, Mongolia - $24 \%$. Interest in the «compliance» concept, presented in English, was reflected in requests from such countries (the first ten most frequently used countries in the world): St. Helena Island - $100 \%$, Singapore $-75 \%$, Hong Kong - $73 \%$, Luxembourg - $73 \%$, Australia $71 \%$, South Africa $68 \%$, New Zealand $60 \%$, Kenya $53 \%$, USA $53 \%$, Ireland $51 \%$.

In order to obtain a greater visualization of the total frequency of users' search queries in the world according to the analyzed concepts «Комплаенс» and «Compliance», frequency distribution diagrams were built for each of the concepts in Fig. 1, 2, respectively.
As seen from Fig. 1, characteristic, given the frequency of user searches, a tendency for the most part constant, starting from February 2010. From this period, every month there was a search on this topic, not once in a month was there a zero (or close to zero) value of the frequency of search queries, just in the post-crisis period. The stabilization of the situation in the world already in the post-crisis periods did not lead to the opposite trend towards a decrease in the frequency of search queries, but, on the contrary, the restoration of the upward trend in 2012.

As seen from Fig. 2, the diagram shows a stable trend, since 01.2004, the frequency of search queries is the term «Compliance». This may be due to the understanding of users (scientists, practitioners, etc.), including in English, the relevance of issues of development of the organization of compliance in various areas.

In order to determine trends, modeling the level of interest of Internet users with the considered concepts, trend lines with a forecast for 12 months have been added to the distribution diagrams (approximation functions are constructed, Fig. 3, 4). For the «Комплаенс» concept the built trend line is adequate and reliable, since the high $\mathrm{R}^{2}$ value (Fig. 3).

However, for the «Compliance» concept according to the data based on the frequency of user requests, starting from 2004, a predictive model was built, the $\mathrm{R}^{2}$ value was unsatisfactory and was unreliable. In order to build the most reliable model, the initial forecasting period was changed from 2004 to 2010 . This made it possible to build a predictive model with $\mathrm{R}^{2}$ is 0.7507 (Fig. 4).

The constructed trend lines and the obtained approximation functions, which can confirm the significance of the results obtained in predicting the frequency of search queries of users in the world in terms of compliance in Russian and English, are given in Table 2.

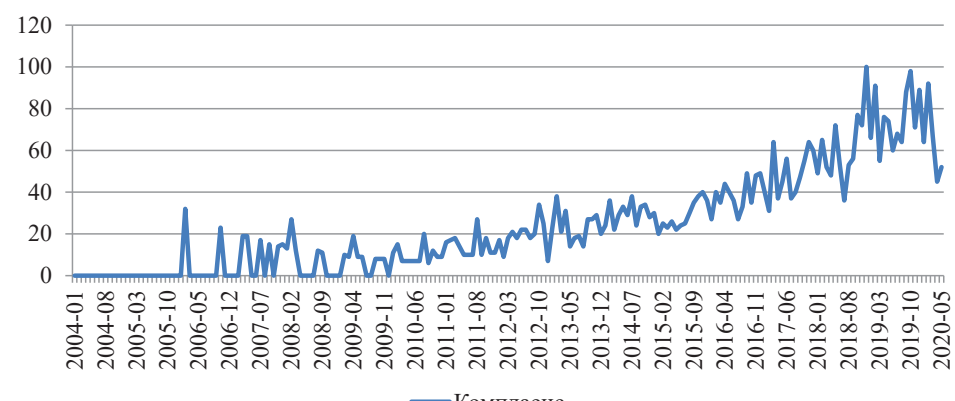

Fig. 1. Diagram of the distribution of the frequency of users' search queries in the world for the «Koмnлаeнг» concept, since 2004 (built on the basis of data from Google Trends by the source [16])

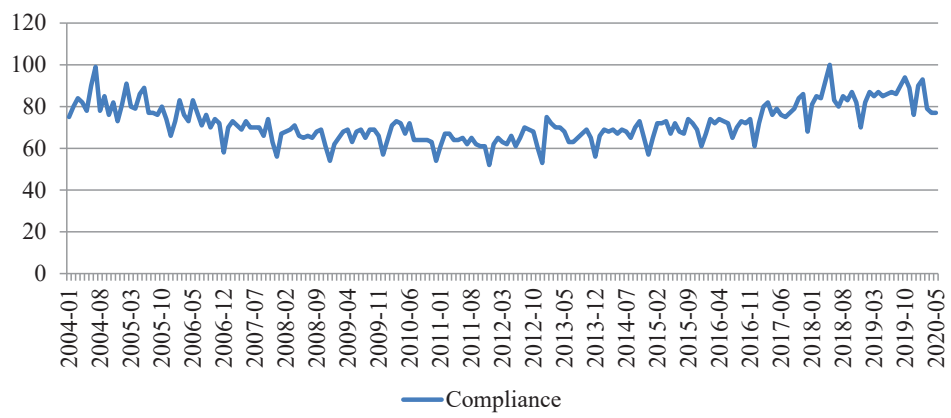

Fig. 2. Diagram of the distribution of the frequency of search queries of users in the world for the "Compliance» concept, since 2004 (built on the basis of data from Google Trends by the source [16]) 


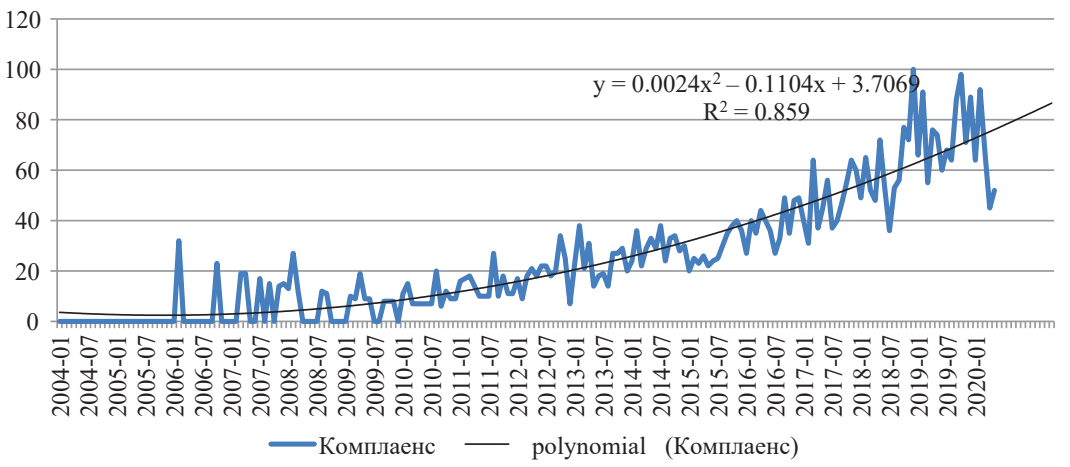

Fig. 3. Forecasting the level of user interest in the «Комплаенс» concept oin the world, starting from 2004 (built on the basis of data from Google Trends according to the source [16])

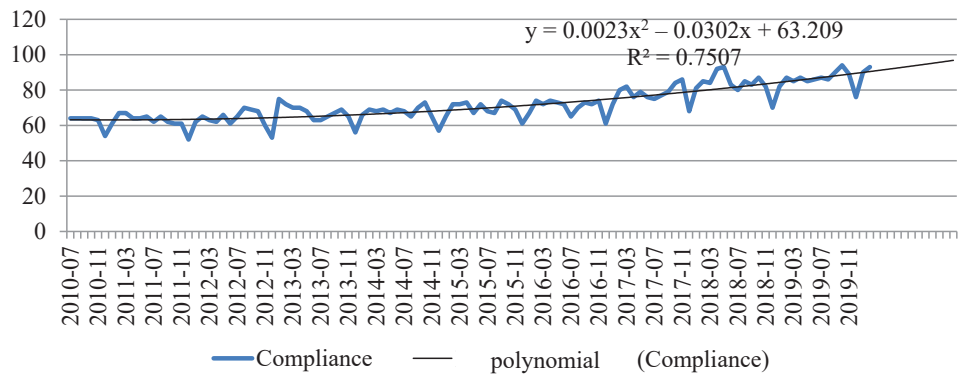

Fig. 4. Forecasting the level of interest of users in the world by the «Compliance» concept, starting from 2010 (based on data from Google Trends according to the source [16])

Table 2

Approximation functions of the considered concepts according to the frequency of search queries of users in the world

\begin{tabular}{|c|c|c|}
\hline Concept & Approximation function & Approximation reliability \\
\hline Комплаенг & $y=0.0024 x^{2}-0.1104 x+3.7069$ & $\mathrm{R}^{2}=0.859$ \\
\hline Compliance & $y=0.0023 x^{2}-0.0302 x+63.209$ & $\mathrm{R}^{2}=0.7507$ \\
\hline
\end{tabular}

Note: based on data from Google Trends by source [16]

As it is possible to see from the Table 2, the trend line of the considered «Комплаенс» concept is built according to the frequency of search queries of users in the world has a satisfactory (0.859) value of the approximation reliability. To build a trend line for another concept under consideration, the research period has been changed (since 2010). This is due to the fact that the built functions of approximation by statistical sampling (monthly, since 2004) were with low $\mathrm{R}^{2}$.

As seen from Fig. 3, 4 and Table 2, the results obtained confirm the interest and strengthening of the role, importance and relevance of compliance research, confirm the relevance of this area of research in the world.
In order to analyze the interest of stakeholders in Ukraine in information about the concepts «Комплаєнс», «Комплаенс», «Compliance», the dynamics of the volume of the frequency of search queries for these concepts, starting from 2004, was determined. Further, in order to obtain a greater visualization of the total frequency of search queries of users in Ukraine, according to the analyzed concepts, diagrams of the distribution of the frequency of these search queries are built, shown in Fig. 5-7.

As seen from Fig. 5, the diagram characterizes a gradual increase in the frequency of search queries for the «Комплаєнс» concept, starting in 2011, and the presence of stable monitoring of this concept begins in 2019. There is a trend towards narrowing the search volume gap for this concept.

As seen from Fig. 6, 7, it is advisable to draw a general conclusion about the interest of users in Ukraine and information about the concepts of «Комплаенс» and «Compliance», since the frequency of search queries is consistently low, especially since 2011-2012. A slight increase in the frequency of search queries begins in 2018-2019. These changes can be associated with globalization processes in the world and their impact.

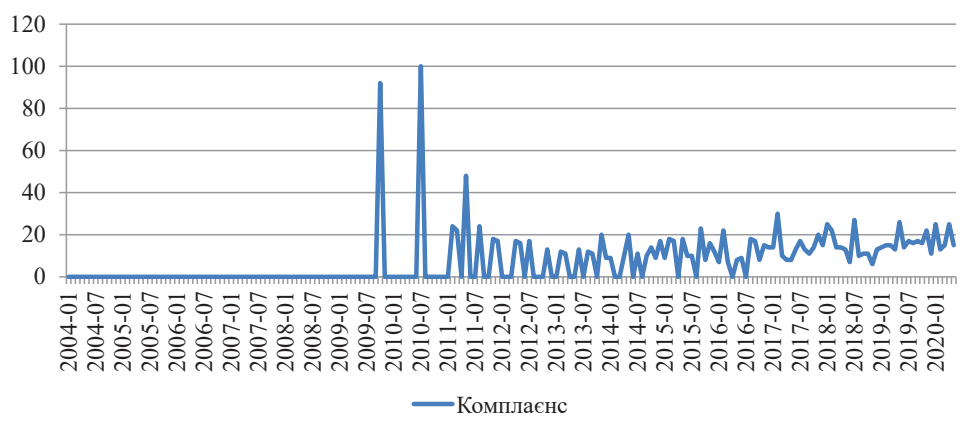

Fig. 5. Frequency distribution diagram of user search queries in Ukraine for the «Комплавнг» concept, since 2004 (built on the basis of data from Google Trends by the source [16]) 


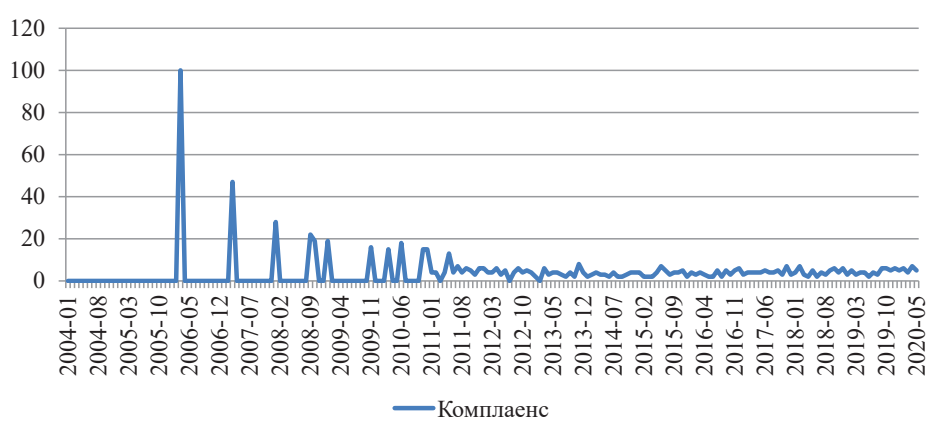

Fig. 6. Frequency distribution diagram of user search queries in Ukraine for the «Комплаенс» concept, since 2004 (built on the basis of data from Google Trends by the source [16])

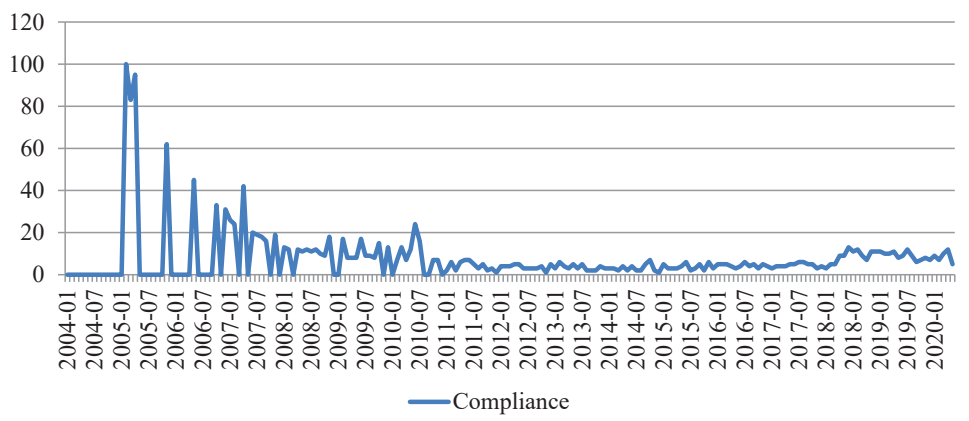

Fig. 7. Frequency distribution diagram of search queries of users in Ukraine for the «Compliane» concept in English, since 2004 (built on the basis of data from Google Trends according to the source [16])

At the same time, the interest in organizing compliance can be explained by the fact that Ukraine has developed draft laws of Ukraine [1,2]. The main innovations of these projects are the introduction in Ukraine of a system of compulsory accumulative pension provision, that is, the second tier of the pension system and the introduction of requirements for organizing compliance in the activities of entities that carry out accumulative pension provision. In addition, compliance has become widespread in the field of organizing financial monitoring in Ukrainian banks.

In order to build predictive models for each of the distribution diagrams of a part of search queries (Fig. 5-7), trend lines have been added. However, even when constructing models of polynomial trends of the sixth degree, which served to obtain a larger $\mathrm{R}^{2}$ value, the obtained models had a low reliability for forecasting but were not adequate.

Consequently, the given distribution in Fig. $5-7$ is quite robust, which demonstrates a gradual decline in research in this area with very little growth since 2018. These data may indicate a possible underestimation of the importance of a deeper analysis of information on the organization of compliance in various areas. The decrease in user interest indicates that this direction is not yet in demand, given the prevalence and relevance.

6.2. Using the Decision Making Helper to decide the key components of a funded pension compliance organization. As defined in section 6.1, the global trend is to increase the level of user interest in compliance issues, which is determined taking into account the language characteristics.

The presence of legislative initiatives developed in Ukraine [1,2] on the introduction of a system of compulsory funded pension provision has confirmed the importance of considering the issues of organizing compliance on the basis of decision-making. So, the expediency of introducing requirements for the organization of compliance in the activities of entities providing accumulative pension provision has been confirmed.

For this purpose, on the basis of the aforementioned legislative projects, a list of criteria for assessing the organization of compliance in the field of accumulative pension provision is provided (Table 3 ).

Table 3

Criteria for assessing compliance organization in the field of funded pension provision*

\begin{tabular}{l}
\hline \multicolumn{1}{c|}{ Criterion } \\
\hline Having an established, permanent and effective compliance unit \\
\hline Compliance risk management system \\
Availability of a system for assessing the effectiveness of the compliance \\
system \\
\hline $\begin{array}{l}\text { Presence of a description of the internal rules and procedures governing } \\
\text { all internal processes }\end{array}$ \\
\hline $\begin{array}{l}\text { Description of how the compliance functions are integrated into the manage- } \\
\text { ment and decision-making processes }\end{array}$ \\
\hline Availability of a compliance risk assessment system \\
\hline $\begin{array}{l}\text { Description of the ways in which conflicts of interest are avoided, including } \\
\text { the prevention of conflicts of interest for persons performing key functions }\end{array}$ \\
\hline Existence of a mechanism for monitoring the complaint process \\
\hline $\begin{array}{l}\text { Availability of verification of compliance by employees with approved internal } \\
\text { rules and procedures, using control procedures and methods of verification } \\
\text { provided for by the regulation on the organization of control }\end{array}$
\end{tabular}

Note: ${ }^{*}$ - criteria are determined according to the source [1]

Requirements for the organization of compliance in the field of financial monitoring (for example, banks) are given in Table 4.

Based on the Tables 3, 4 there are three blocks of compliance organization: organizational, methodological and process aspects. 
Requirements for the organization of compliance in the field of financial monitoring (for example, banks)

\begin{tabular}{|c|c|}
\hline Requirements & Source \\
\hline Presence of a department for monitoring compliance with standards (compliance) & [17] \\
\hline Financial monitoring and/or compliance unit & [18] \\
\hline Determine the grounds for making changes/approving new editions of the bank's internal documents during the reporting period & [18] \\
\hline How often were internal documents reviewed during the reporting period? & [18] \\
\hline $\begin{array}{l}\text { Or the mechanism available in the bank for tracking changes in the legislation on combating money laundering, terrorist financing (hereinafter, } \\
\text { CML/TF) with the aim of introducing them into internal documents? }\end{array}$ & [18] \\
\hline $\begin{array}{l}\text { How many times during the reporting period did the bank's responsible employee or the person who was assigned the duties of the bank's } \\
\text { responsible employee change (in the absence of a responsible employee approved by the National Bank of Ukraine)? }\end{array}$ & [18] \\
\hline Ог аге other areas of the bank's activities subordinate to the responsible employee of the bank, except for the division for financial monitoring? & [18] \\
\hline $\begin{array}{l}\text { What proportion of the working time of a responsible employee does it devote to CML/TF issues, in the total working time (the answer is } \\
\text { provided in percentage)? }\end{array}$ & [18] \\
\hline $\begin{array}{l}\text { How often did the responsible employee or employee of the bank, an authorized employee in charge during the reporting period carry out } \\
\text { inspections of the bank's divisions and its employees regarding their compliance with internal documents on financial monitoring? }\end{array}$ & [18] \\
\hline Does the bank provide for the liability of bank employees in case of non-fulfillment/improper fulfillment of their duties in the field of CML/TF? & [18] \\
\hline Аге there cases of bringing the bank's employees to responsibility during the reporting period in accordance with the bank's internal procedures? & [18] \\
\hline $\begin{array}{l}\text { Availability of verification of compliance by employees with approved internal rules and procedures, using control procedures and methods of } \\
\text { verification provided for by the regulation on the organization of control }\end{array}$ & [18] \\
\hline
\end{tabular}

To assess the alternatives of the key components of the compliance organization, the DSS Decision Making Helper was used in the online version, that is, with a maximum number of three criteria and three alternatives.

The DSS Decision Making Helper is based on an expert method of evaluating possible alternatives. This system is widely used primarily due to its availability on the Internet. Any user can access the product in real time via a link on the Internet, which will allow to receive a free demo version of the software product, limited to three selection criteria. To study more criteria, it is necessary to use the paid access to the program [4].

To enter data into the DSS Decision Making Helper in order to make a decision about the key components of the organization, the compliance level is determined by moving the arrow to the required rating. The rating is applied in such a way from -5 «maximum unfavorable» to +5 «most favorable» 0 - neutral [19].

Evaluating the most important components for organizing compliance in the field of funded pension provision is done using the DSS Decision Making Helper. Block A - organizational aspects, block B - methodological aspects and block $\mathrm{C}$ - process aspects of the organization of compliance were subject to assessment, the results of which are shown in Table 5 .

Based on the data in the Table 5, which were determined by the expert ranking method, information was entered into the DSS Decision Making Helper, which is shown in Fig. 8.

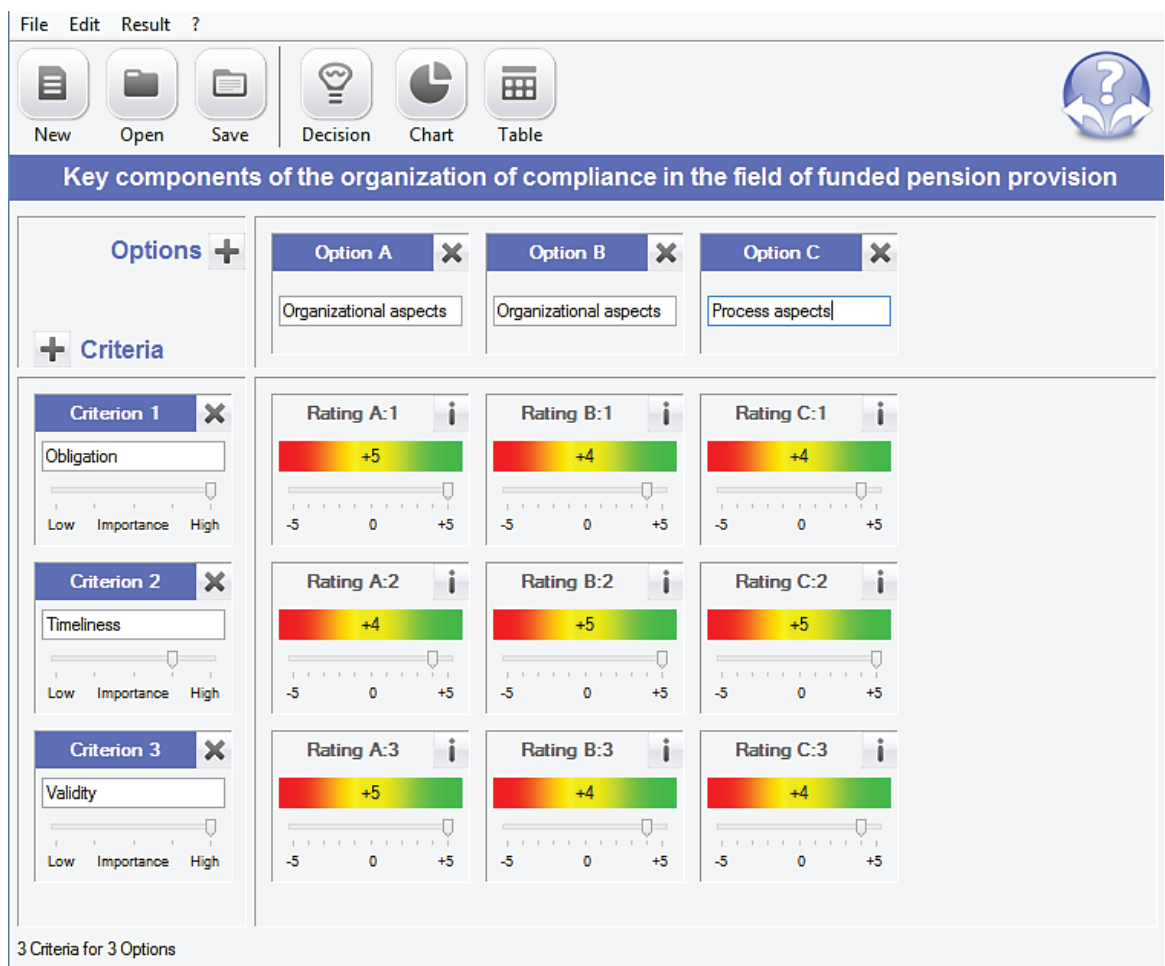

Fig. 8. Completed Decision Making Helper window for evaluating alternatives of key components of the organization of compliance in the field of funded pension provision (used by Decision Making Helper according to the source [19]) 
Based on the data shown in Fig. 8, the final results of using the DSS Decision Making Helper [19] were obtained to make decisions about the key components of the organization's compliance (Fig. 9, 10).

The DSS Decision Making Helper provides automatically the characteristic decision in percentage from $-100 \%$ to $+100 \%$ and in the words «unsatisfactory/rather unsatisfactory/neutral/rather positive/positive» [19].

As seen from Fig. 9, 10, organizational aspects are of the highest priority and priority in organizing compliance in the field of funded pension provision, taking into account the characterization of the decision as the most positive. This may include the creation of an appropriate compliance control unit (compliance).

Decision for "Key components of the organization of compliance in the field of funded pe

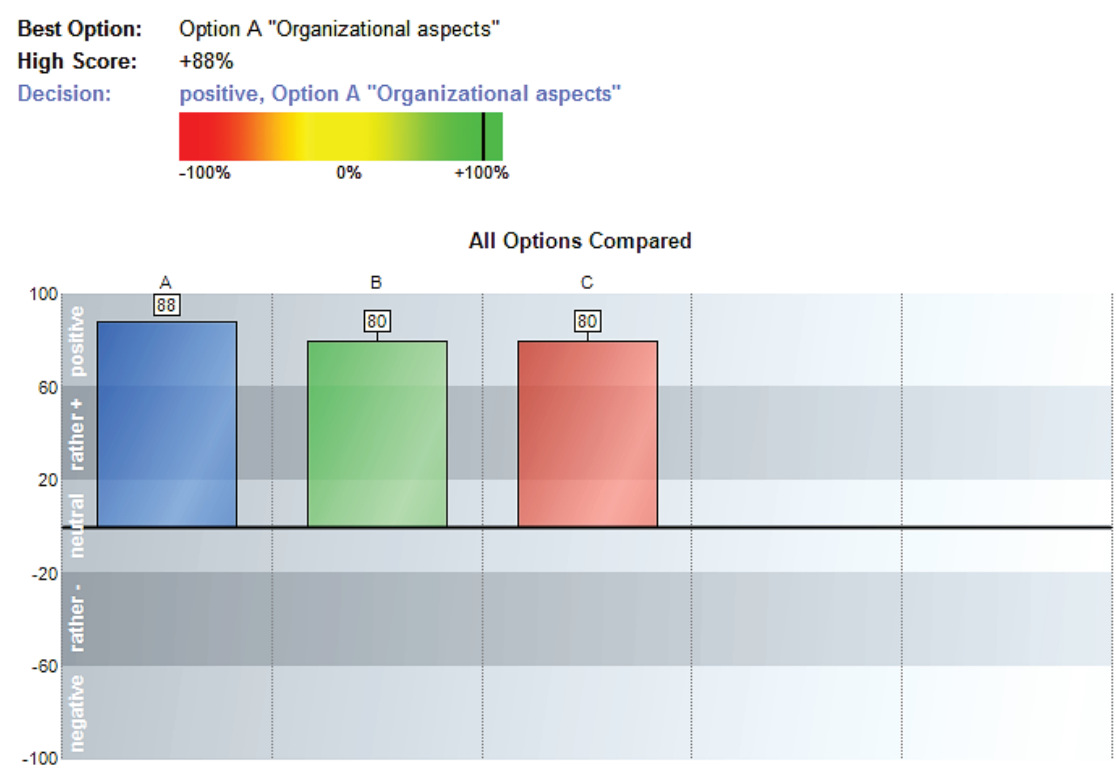

Fig. 9. The final window with the results in the Decision Making Helper on the alternatives of the key components of the organization of compliance in the field of funded pension provision (built using the Decision Making Helper according to the source [19])

\section{Radar Chart for "Key components of the organization of compliance in the field of funded}

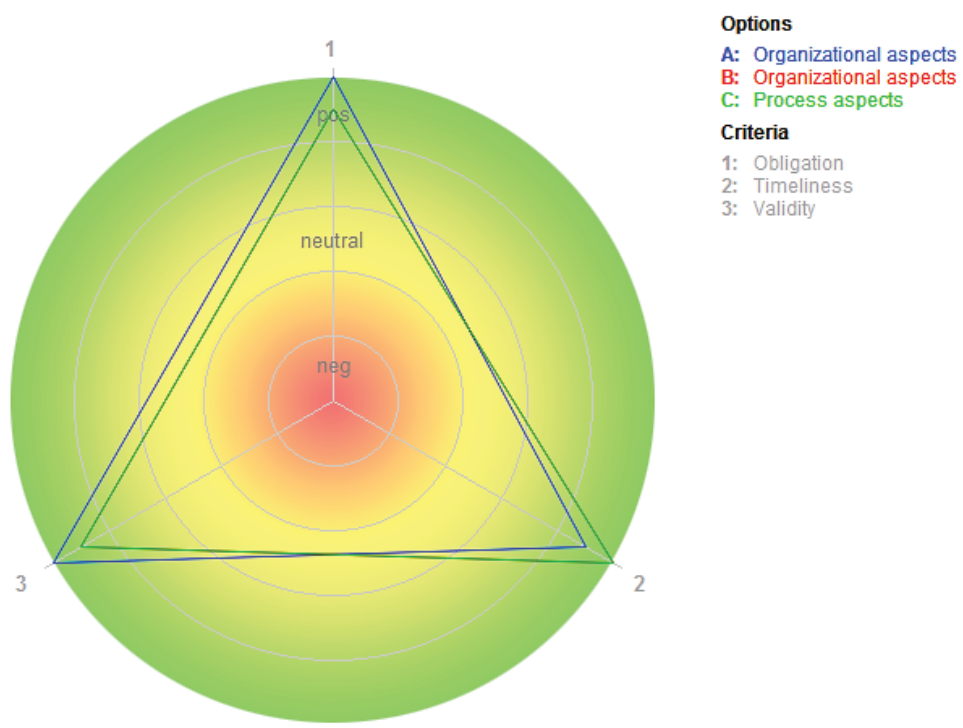

Fig. 10. Final window with results in the Decision Making Helper on alternatives to the key components of the organization of compliance in the field of funded retirement (radar method) (built using Decision Making Helper from source [19])

\section{SWOT analysis of research results}

Strengths. The approach to assessing the level of user a reserch is to identify trends and current tiends al thought on the organization of compliance. The use the organization of complice in the field of funded retirement benefits by means of Making Helper will automate this process.

Weaknesses. The process of assessing the level of interest Trends search engine on the topic of compliance is quite laborious.

Opportunities. Opportunities for further research are the development of an approach to the organization of compliance in the field of funded pension provision (alternatives of key components) based on the definition and detailing of the organizational, methodological and process aspects of its organization.

Threats. Implementation of the DSS Decision Making Helper in the organization of compliance in the field of funded retirement will require the purchase of a license by stakeholders, the cost of which will depend on the number of computers to install.

\section{Conclusions}

1. Based on the analysis of users' interest in searching for information on the «комплаєнс» concepts in Ukrainian, Russian and English, the frequency of their search queries for data has been analyzed since 2004 . Based on the analysis of the frequency of search queries of users in the world, obtained using the search engine Google Trends, since 2004, the distribution of the frequency of queries is analyzed. The results obtained confirm the interest and strengthening of the role, importance and relevance of compliance research, as well as the relevance of this area of research in the world. The lines of trends for the definition of the approximation function for the considered concepts of «комплаенс» and «compliance» are plotted according to the frequency of users' search queries in the world. The resulting trend models have a satisfactory (0.859 and 0.7507$)$ value of the approximation reliability and are recommended for predicting the level of user interest in the world. At the same time, the trend models built based on the frequency of user requests in Ukraine had low 
reliability for forecasting and were not adequate enough. The analysis of the frequency of search queries of users in Ukraine is quite contradictory, demonstrates a gradual decline in research in this area with very insignificant growth since 2018 .

2 . Based on the analysis of legislative projects providing for the introduction of a compulsory system of funded pension provision, a list of criteria for assessing compliance organizations is presented. Assessment of alternatives for the key components of the organization's compliance in the area of funded pension provision is obtained using the Decision Making Helper decision support system. A multi-criteria assessment of the key components of a compliance organization in the area of funded pension provision was carried out on the basis of the following criteria (with a corresponding weight from -5 to +5$)$ : obligation $(+5)$; timeliness $(+4)$; validity $(+5)$. The priority of the organizational aspect is determined, it has the characteristic of the most positive decision, since this characteristic was $+88 \%$.

\section{Acknowledgement}

The work is prepared and financed within the framework of the state budget research work No. 45/2020-2021 «Formation of a risk-oriented system of accumulative pension provision» (DR No. 0120U101508).

\section{References}

1. Pro zahalnooboviazkove nakopychuvalne pensiine zabezpechennia (2019). Proiekt Zakonu Ukrainy No. 2683. 27.12.2019. Available at: http://search.ligazakon.ua/l doc2.nsf/link1/JI01073A.html

2. Pro zahalnooboviazkove nakopychuvalne pensiine zabezpechennia (2018). Proiekt Zakonu Ukrainy, shcho pidhotovleno Natsionalnoiu komisiieiu $\mathrm{z}$ tsinnykh paperiv ta fondovoho rynku. Available at: https://www.nssmc.gov.ua/proects_of_regular/ proekt-zakonu-ukrani-pro-zagalynoobovvyazkove-nakopitchuvalyne-pensyne-zabezpetchennya

3. Dumanskyi, N. O., Markovets, O. V. (2009). Intelektualna systema poshuku ta zbyrannia informatsii z tematychnykh vebresursiv. Informatsiini systemy ta merezhi: Visnyk Natsionalnoho universytetu «Lvivska politekhnika», 631, 101-106.

4. Kliuiev, O., Vnukova, N., Hlibko, S., Brynza, N., Davydenko, D. (2020). Estimation of the Level of Interest and Modeling of the Topic of Innovation Through Search in Google. Proceedings of the 4th International Conference on Computational Linguistics and Intelligent Systems (COLINS 2020), 523-535.

5. Awad, A., Decker, G., Weske, M. (2008). Efficient Compliance Checking Using BPMN-Q and Temporal Logic. Business Process Management, 326-341. doi: http://doi.org/10.1007/9783-540-85758-7_24

6. Awad, A., Smirnov, S., Weske, M. Meersman, R., Dillon, T., Herrero, P. (Eds.) (2009). Resolution of Compliance Violation in Business Process Models: A Planning-Based Approach. On the Move to Meaningful Internet Systems: OTM 2009. Lecture Notes in Computer Science, 5870, 6-23. doi: http://doi.org/ 10.1007/978-3-642-05148-7_4

7. Barnawi, A., Awad, A., Elgammal, A., Elshawi, R., Almalaise, A. Sakr, S. (2016). An Anti-Pattern-based Runtime Business Process Compliance Monitoring Framework. International Journal of Advanced Computer Science and Applications, 7 (2), 551-572. doi: http://doi.org/10.14569/ijacsa.2016.070272

8. Thullner, R., Rozsnyai, S., Schiefer, J., Obweger, H., Suntinger, M. (2011). Proactive business process compliance monitoring with event-based systems. IEEE 15th International Enterprise Distributed Object Computing Conference Workshops (EDOCW), 429-437. doi: http://doi.org/10.1109/edocw.2011.22

9. SRO Consultative committee of the international organization of securities commissions (2003). The function of compliance officer. Available at: http://www.cnmv.es/publicaciones/IOSCO.pdf

10. Isa, Y. M., Sanusi, Z. M., Haniff, M. N., Barnes, P. A. (2015). Money Laundering Risk: From the Bankers' and Regulators Perspectives. Procedia Economics and Finance, 28, 7-13. doi: http:// doi.org/10.1016/s2212-5671(15)01075-8

11. Basel Committee on Banking Supervision (2005). Compliance and the compliance functions in banks. Available at: https:// wwwbis.org/publ/bcbs113.pdf

12. Liubovets, H. V. (2015). Poshukovi systemy v merezhakh Internetu. Zbirnyk naukovykh prats Viiskovoho instytutu Kyivskoho natsionalnoho universytetu imeni Tarasa Shevchenka, 50, 202-210.

13. Vorotyntsev, M. M. (2014). Analiz dynamiky ta aktualnosti naukovykh doslidzhen u sferi otsinky ryzyku kredytuvannia finansovykh. Biznes Inform, 11, 280-286.

14. Ukrainski kompanii pochaly vprovadzhuvaty komplaiens-kontrol. Shcho tse i navishcho? (2019). Available at: https://youcontrol. com.ua/blog/komplaiens-kontrol-shcho-tse-i-navishcho/

15. Kavun, S. V., Vorotyntsev, M. M. (2016). Credit Risk Assessment for Financial Institutions Activity. Journal of Finance and Economics, 4, 142-150.

16. Google Trends. Available at: https://trends.google.com.ua/ trends $/$ ?geo $=\mathrm{UA}$

17. Pro zatverdzhennia Polozhennia pro orhanizatsiiu systemy vnutrishnoho kontroliu v bankakh Ukrainy ta bankivskykh hrupakh (2019). Postanova Pravlinnia Natsionalnoho banku Ukrainy No. 88. 02.07.2019. Available at: https://zakon.rada.gov.ua/ laws/show/v0088500-19

18. Pro zatverdzhennia Zmin do Polozhennia pro poriadok orhanizatsii ta provedennia perevirok z pytan zapobihannia ta protydi lehalizatsii (vidmyvanniu) dokhodiv, oderzhanykh zlochynnym shliakhom, finansuvanniu teroryzmu ta finansuvanniu rozpovsiudzhennia zbroi masovoho znyshchennia (2018). Postanova Pravlinnia Natsionalnoho banku Ukrainy No. 59. 05.06.2018. Available at: https://zakon.rada.gov.ua/laws/show/v0059500-18

19. Decision Making Helper. Available at: https://www.infonauticssoftware.ch/decisionmakinghelper/

Achkasova Svitlana, PhD, Associate Professor, Department of Banking and Financial Services, Simon Kuznets Kharkiv National University of Economics, Ukraine, e-mail: svet_achk@meta.ua, ORCID: http:// orcid.org/0000-0001-7233-0189 